\title{
Five Cent Music: Publication of an Early Series of Canadian Sheet Music by Peter A. Higham*
}

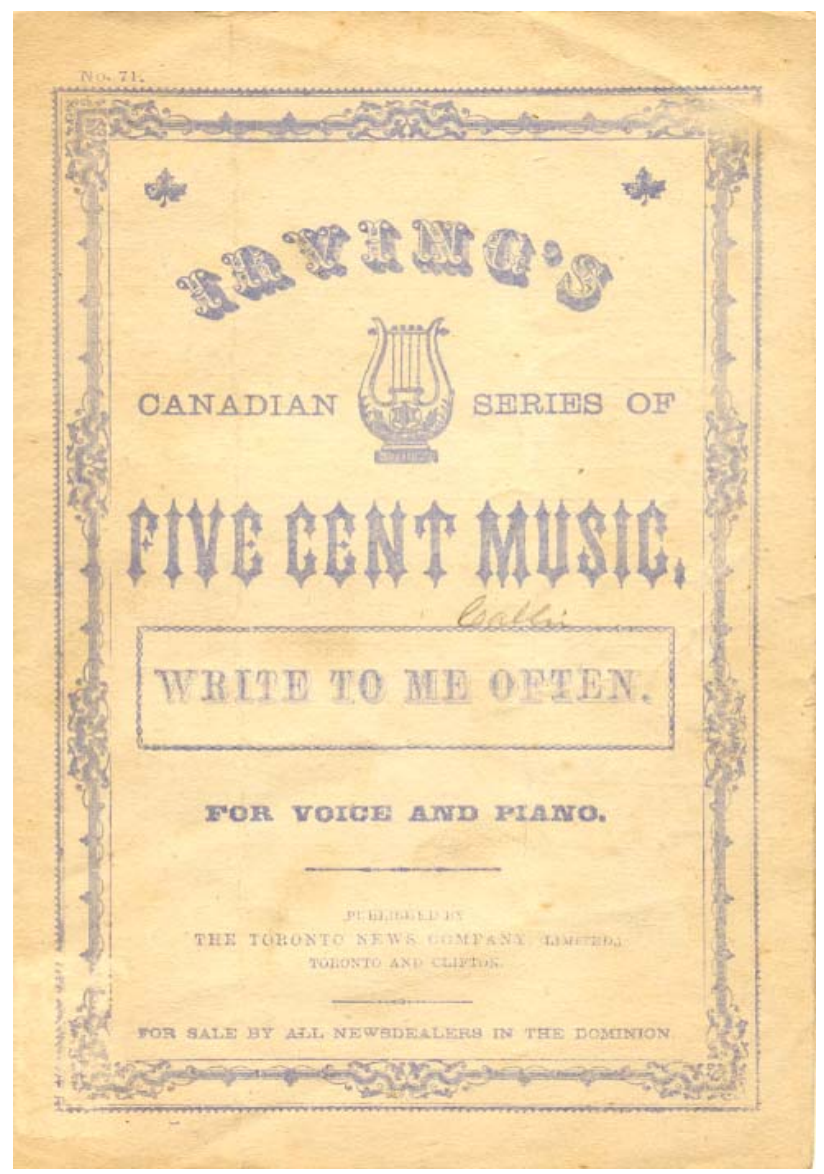

The little that is known about Irving's Canadian series of five cent music is encompassed in an article by Dr. Helmut Kallmann included in The Encyclopedia of music in Canada (Kallmann 1992a, 637). This Series of 750 sheet music issues was published in Toronto and Clifton (Niagara Falls) by the Toronto News Company and in Montreal by the Montreal News Company. The popular songs of the day were issued without copyright notice or an indication of

\footnotetext{
* ${ }^{\circ} 2009$ The author and the Canadian Association of Music Libraries, Archives, and Documentation Centres/L'auteur et l'Association canadienne des bibliothèques, archives et centres de documentation musicaux.
} 
the year of publication; it was thought, however, that most were published in the 1880s and a majority of those issues which have been catalogued and whose bibliographic records appear in the Amicus database, indicate the probable years of publication as 1880 to 1885 (Amicus catalogue). However, bibliographic records for issues held by Library and Archives Canada guess that number three in the Series was published between 1867 and 1873, and number six between 1871 and 1874 . Those bibliographic records also indicate that 1885 is the probable date of publication for titles near the end of the Series. Information below indicates more precisely the years of publication in Canada of this large sheet music series.

In his book The Beginnings of the book trade in Canada George L. Parker mentions the Toronto News Company in the context of mail-order book companies, such as Rose-Belford's Library and Robertson's Popular Library. Managed by Andrew S. Irving, the Toronto News Company issued its own American Library, whose titles were light reading by authors such as Joaquin Miller, Fleming and Roe. "The library series filled an important economic and cultural role because for the first time in our history, Canadian publishers supplied literature at affordable prices to everyone who could read" (Parker 1985, 196). This can be affirmed in a parallel manner to the publication and availability of sheet music during the same period. The Canadian Institute of Historical Microreproductions reproduced, in microfiche format (CIHM no. 92361), a short piece of fiction entitled, "The Hidden Hand," by Mrs. [Emma Dorothy Eliza Nevitte] Southworth. It was published by the same Toronto News, publishers, in Toronto and Niagara Falls, Ont. Following the eighty-six pages of text is a list which advertises song titles numbered one through 501 from the series Irving's Five Cent Music. If the year of publication of this item was as CIHM established, i.e., between 1874 and 1876, then two-thirds of Irving's Five Cent Music Series must have been published by 1876 .

A Dictionary of Toronto printers, publishers, booksellers and the allied trades, 1798-1900 by Elizabeth Hulse supplies more details about the Toronto News Company. It was originally incorporated as the Canadian News Company, but changed its name and became active as the Toronto News Company in July of 1876, as a wholesale bookseller, stationer, and newsdealer; a publisher; publishers' agent; sheet music publisher; and sporting goods dealer (Hulse 1982, 262). Hulse does not indicate the demise of the company, but it was still active in 1888 when it published John Marchant Whyte's "The Land of No-Where," a copy of which is held by the Archives and Research Collections at McMaster University (email message to the author from Archivist Librarian Rick Stapleton, 3 February 2009). 




Hulse gives the location of the Toronto News Company as 14 Jordan Street from 1877 to 1881, and as 42 Yonge Street from 1882. As already noted, the year of publication is not indicated on the issues in Irving's Five Cent Music. These street addresses would help to establish what years Irving's Series was published, because most of the issues indicate the three places of publication. However, only the Montreal location carries a street address. It has not been determined what years the Montreal News Company existed at its different addresses, which included 588 Craig Street and 386 and 388 St. James Street. There was an overlap between the Toronto News Company and its predecessor, Irving \& Co. (February 1874 - September 1876), since early numbers (including numbers 1, 2, and 6) in the Five Cent Music series carry the address of 35 King Street Toronto, which was the address of Irving \& Co. (Hulse 1982, 132). Because 
numbers 49 and 50 of the Series indicate the address of Jordan Street, it may be surmised that Irving's Canadian Series of Five Cent Music began between 1874 and 1876, probably closer to 1876. It was finished by 1888, when the previously mentioned song, "The Land of No-Where," was published by the Toronto News Company, but the sheet music itself does not carry a Series number or refer to the Series title.

Hulse also provides further information about Andrew Scott Irving, who was manager and later president and managing director of the Toronto News Company (1982, 133). He was born in Scotland in 1837 or 1839 and was active in Toronto as a bookseller, stationer, newsdealer, publisher, and music publisher from 1862 until his death in 1904. Besides the Toronto News Company, which had branches in Clifton and Montreal (the Montreal News Company), he was involved with other companies, including Irving \& Thomson, Canadian News and Publishing Co., Irving \& Co., and the National Electrotype \& Stereotype Co. He published, under the name of A. S. Irving, a ninety-six-page book of song-texts, measuring fifteen centimeters high, called The Canadian Maple Leaf Song Book. It was supposedly published between 1867 and 1872 (Amicus catalogue).

The Encyclopedia of Music in Canada article indicates that "nearly 700 numbered items" were published, but Library and Archives Canada actually holds what appear to be among the last of the Series, number 748, "I Loved You Better than You Knew" and number 749, "My Dad's the Engineer." It is surprising that Rare Books and Special Collections of McGill University Library has only five of the Series, but it does hold a copy of what appears to be the final number, 750, entitled "Sweet Bunch of Daisies." The back page of most sheet music issues normally includes a list of the Series issue numbers along with the accompanying song titles. The last title in the numbered lists is number 744. The author has collated into a single complete list the song titles and their Series issue numbers [see appendix 1]. Because of an entry in the WorldCat catalogue, it was thought that someone had previously made a complete list of the Series titles. The entry indicates that Brown University Library in Providence, Rhode Island has a copy of a book published in Saint John, New Brunswick in 1890 with the title, List of Irving's Five Cent Music: containing all the new and popular songs of the day (WorldCat). However, it turns out that the item is, in reality, a single broadsheet with only 501 titles of the whole Series in its list. 

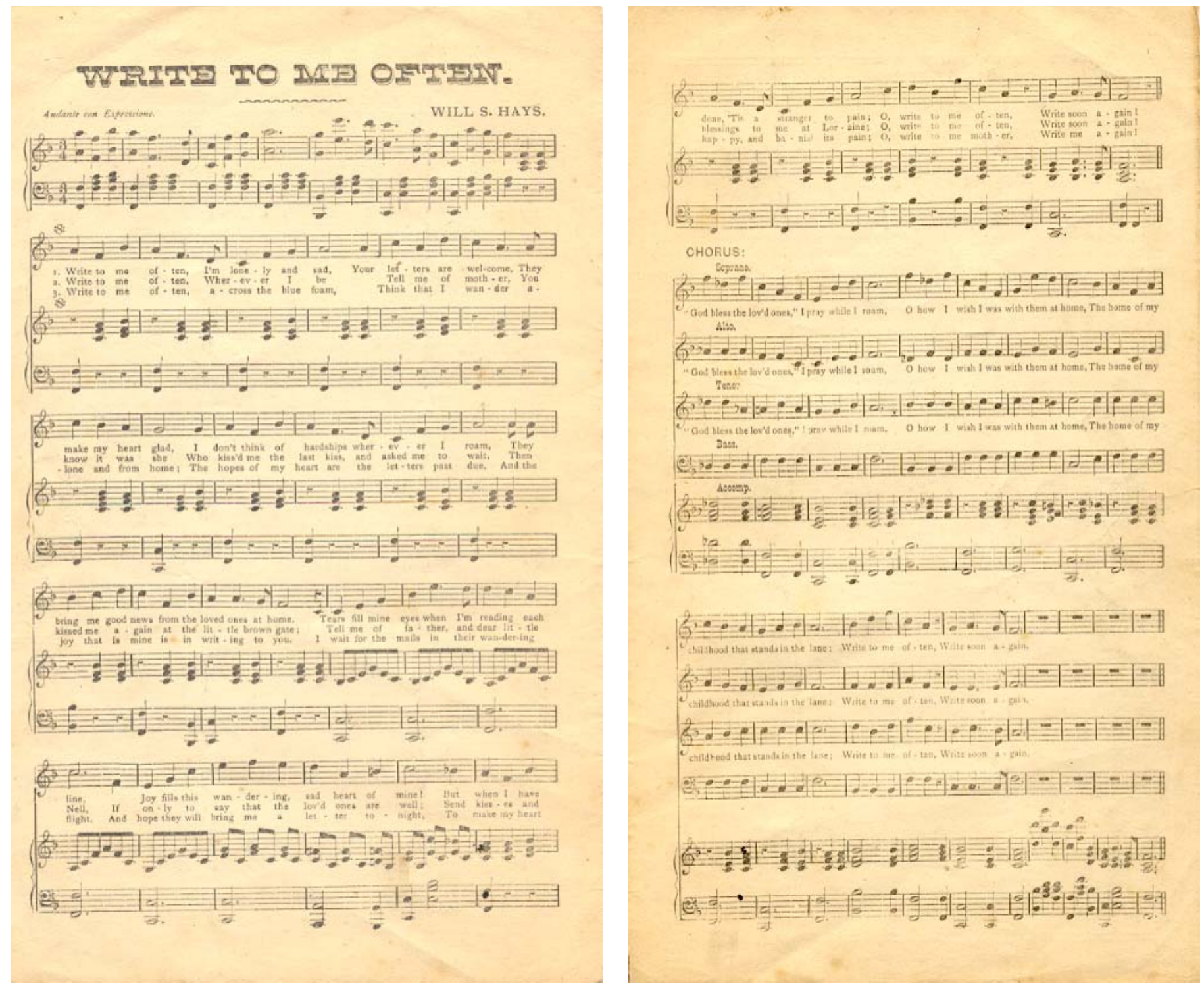

The songs were published in octavo format: single sheets which probably before trimming measured 11 by 14 inches $(28 \times 35.5 \mathrm{~cm}$.). When folded the sheets produced a title page, the music on the inside two pages, and the back page which, as already mentioned, normally listed numbered titles from the Series. The folded sheets measure 17 by $26.5 \mathrm{~cm}$. 

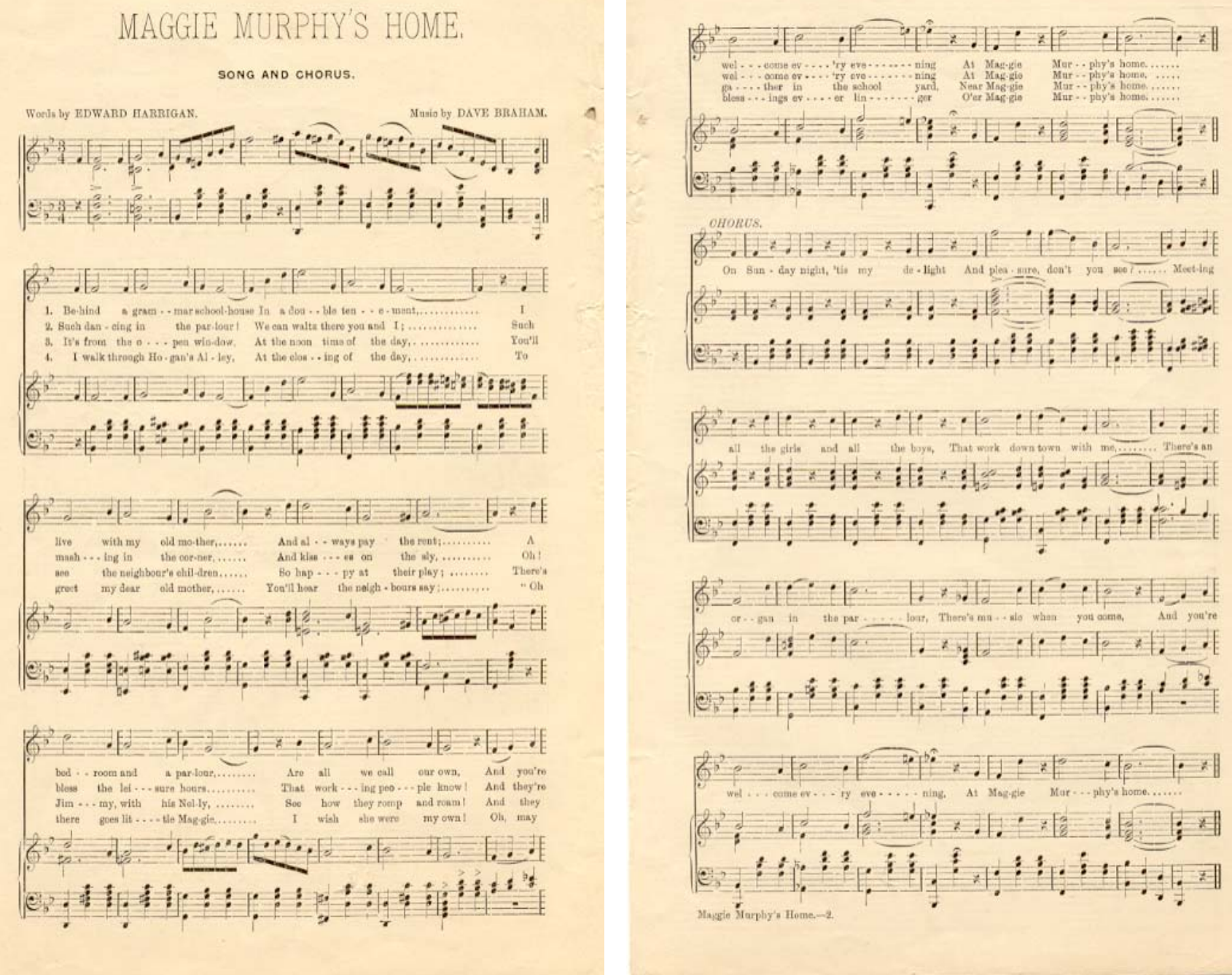

It is not so surprising that the song Series was published, not by a music publisher, but by a socalled news company. This, of course, was some forty years before the time of radio, so what better way of 'broadcasting' the typical songs of the day than by making them easily accessible and affordable in sheet music format? The publication of the sheet music served in its time to make popular songs available to a wider public, and the purpose of the publications would be to get the songs into the hands of many people in a timely manner, something in which a "news" company was experienced. "As a commercial musical marketplace emerged in the closing decades [of the nineteenth century], publishing firms, piano manufacturers, and touring musical shows encouraged the production of music designed to cater to fashionable tastes” (Hall 1985, viii). 
Assuming that number 750 was the last issued in the Series, all titles, except numbers 745, 746, and 747 are known. However, holdings of the Series by different libraries are quite incomplete: a keyword search of WorldCat for "five cent music" produced 492 hits. But few of the hits are relevant to the Series at hand, though at least two other Series showed up: G. Schirmer's octavo church music: five cent series and Cundy's Five cent series of popular music which was published in Boston. There is at least one copy accessible of 57\% of the Series, but that leaves no known holdings for 323 of the sheet music issues. There are just eleven with no holdings from among the first 100 of the Series, but eighty among the last 100 numbers. Mount Allison University Libraries holds thirty-nine of the songs in its rare books collection. At Queens University in the Lorne Pierce Canadian sheet music collection of the W.D. Jordan Special Collections and Music Library are found eighty-eight numbers. To date, somewhat surprisingly, no significant holdings of the Series have been located in one of the publisher's locations, Montreal. The Bibliothèque et Archives nationales du Québec holds just five issues, as does the McGill University Libraries, including, as mentioned previously, the last issue known. Two locations in Toronto have holdings in their special collections: the Toronto Reference Library of the Toronto Public Library system has eighty-two, and the University of Toronto Faculty of Music Library has confirmed holdings of ninety-nine. The latter includes fifty-six of the songs bound together probably by a Walter Goodman Haynes, whose signature appears in the endpaper dated in Toronto, "Sept 29 $/$ 89." This collection is also stamped, "THE RITA HAYNES COLLECTION.”

As might be expected, the largest number of issues of Irving's Canadian Series of Five Cent Music is held at Library and Archives Canada. It has 324, which is still less than half of those issued. Most of these are listed in its catalogue, Amicus, though others have not been fully catalogued. Electronic copies of forty-six of the songs (one appears to be duplicated) are available on the web site Sheet music from Canada's past. No recordings of the songs, however, are available on Collections Canada's music streaming web site The Virtual gramophone: Canadian historical sound recordings.

Most of the titles in the Series are not of significant or of particular interest in themselves, except for indicating popular, mostly American or British, tunes of the day. When putting together the complete list of song titles for the Series, it was necessary to scan several lists. Optical character recognition produced some unlikely titles, such as: "Call Me flack Again," "Be’s the Picture of his addy," “A Faded Pansy," and "When the Moon-Beanie Fall.” But some of the actual titles are just as odd and amusing: "Yakie and Leedle Louvise," "I’m Glad my Heart's my Ain yet," and "The Butterfly Dude." The name "Kathleen" appears in several titles, and one wonders what might have transpired between the earlier song in the Series, "Kathleen’s Answer," and a later one, "I’ve Called you back Again, Kathleen." "Mavourneens” were prolific: there is "Kathleen Mavourneen," "Norah Mavourneen," "Mollie Mavourneen,” and finally, two of "Good-bye, Mavourneen" (numbers 480 and 572). It is not known if these numbers are duplicate songs since 
there are no known holdings of number 572. Other titles elicit curiosity too, like, "Grogan the Masher," and "Creep into Bed, My Baby.” Among my favorite are two titles issued not long before the Series was finished, "I Don’t Want to Play in Your Yard,” and the subsequent (and companion piece?), "You Can’t Play in Our Yard any More.” However, many titles are more recognizable and memorable, even 130 years later: “The Little brown jug," “Old Black Joe,” "Old folks at home,” "Beautiful dreamer," “A Rolling stone gathers no moss," "Hush, little baby, don’t you cry," "Wait till the tide comes in,” and "Irene, good night.”

It seems inevitable that inflation sets in, as witnessed by the few sheet music songs held by the Faculty of Music Library at the University of Toronto in the series, Robertson's Half-Dime Music. These are republications of six of Irving's Five Cent Music, numbers 119, 121, 123, 140, 141, and 163. The Toronto Reference Library owns two issues in a series entitled Irving's Canadian Series of Ten Cent Music which also carry the Five Cent Series' numbers (248 and 253). Unlike their original size they have been published in large format, measuring 26 by 35 centimeters. The back page lists just eight in the Series with the testimonial:

New and popular pieces will rapidly follow. None but the very best will appear in this Series. The above can be had at any Music, Book, or News Store in the dominion, or by enclosing Ten Cents each to the Publishers.

The new Series was perhaps not as popular as anticipated since "Reduced to 5 cents" in large font size is stamped diagonally across the sheet music covers.

Other than the place of publication, there actually is not too much that is Canadian about Irving's Five Cent Music. Out of 750 songs in the Series, only two titles have a Canadian reference and just five were found to be written by Canadian composers or lyricists. Is this an accurate indicator of how Canadian culture was so dominated by British and American influences? Judging by these popular songs of the day, is it any wonder that it was well into the twentieth century before Canada could claim a musical life in a distinctive culture? All the songs having English lyrics is perhaps another reason why so few titles show up in Montreal, where interest in British and American popular songs would be less than in other parts of the country. The parlour songs, ballads, patriotic verses, temperance choruses, and character pieces are largely imported from the British and American music hall, vaudeville stage and other popular entertainments. The choice of publishing these titles in a sheet music series is, to some extent, a mirror of contemporary taste and social life (Kallmann 1988, vol. 3, 1419). The songs are primarily composed for solo voice with keyboard accompaniment, though some are set for four-part chorus. The song-composers are generally not well known. Among the composers who have contributed a greater number of songs to the Series are David Braham with ten, somebody identified only as Claribel (but who was also known as Mrs. Barnard (1830-1869)) with six, Hart Pease Danks with seven, Will. S. Hayes (1837-1907) with nine, Joseph P. Skelly (1853-1895) with eight, and Charles Albert White with five. 
The two "Canadian" song titles are number 114, "Canada: national song and chorus," and number 269, "The Maple Leaf, our Emblem Dear." Only the latter title appears in facsimile in the post-confederation patriotic songs gathered in The Canadian Musical Heritage collection of Songs to English Texts. The copy does not, however, replicate the Toronto News Company edition, but rather one which was published at the Guardian Office on King Street East. Naturally, the names of the composers and lyricists are known only for those songs of which there are holdings locations, that is, about 170 song-writers [see appendix 2]. The five songs which boast Canadian composers or lyricists include Calixa Lavallée's "Beautiful girl of Kildare” (number 55), Frances J. Hatton’s “Canada” (number 114), William Horatio Clarke’s "The Vine-covered Cottage" (number 194), James Austin Butterfield's "When you and I Were Young, Maggie” (number 254), and Alexander Muir's "The Maple Leaf, our Emblem Dear” (number 269). Among these five, Alexander Muir is the only composer represented in the Songs to English Texts volume of The Canadian Music Heritage series.

Most of the songs in the Series were not likely to have been newly composed for the Series; this was the case with Lavallée's "Beautiful girl of Kildare," with words by R. A. Warren, which was originally published by Whittemore in 1869 (Potvin 1992, 728). William Horatio Clarke was the organist-choirmaster at Jarvis Street Baptist Church in Toronto from 1880, and also the father of Herbert L. Clarke (Kallmann and Potvin 1992, 275). One can view the music to his song, "The Vine-covered Cottage," on the Sheet music from Canada's past web site. Here the music is subtitled, "song and chorus; also a quartette and chorus" with words by J. C. Johnson.

The song, "When you and I Were Young, Maggie" has its own entry in the Encyclopedia of music in Canada (Miller 1992, 1399). It was a popular ballad in the early twentieth-century, was recorded by several vocalists and instrumentalists, and was also treated by jazz musicians in the 1930s. The composer, James Butterfield (1837-91) was actually English, but the words were taken from a poem written in Hamilton by George Washington Johnson (1839-1917) for his beloved wife, Maggie Clarke. Butterfield published his song in Indianapolis in 1866, so its appearance in the Irving Canadian Series of Five Cent Music would have been a re-publication. Besides a later American publication of the song, the Sheet music from Canada's past web site displays three versions of it, all published in the Five Cent Music Series, and apparently differing from each other only in their printing and probable year of publication. This indicates that there were multiple printings of at least some of the songs in the Series. 


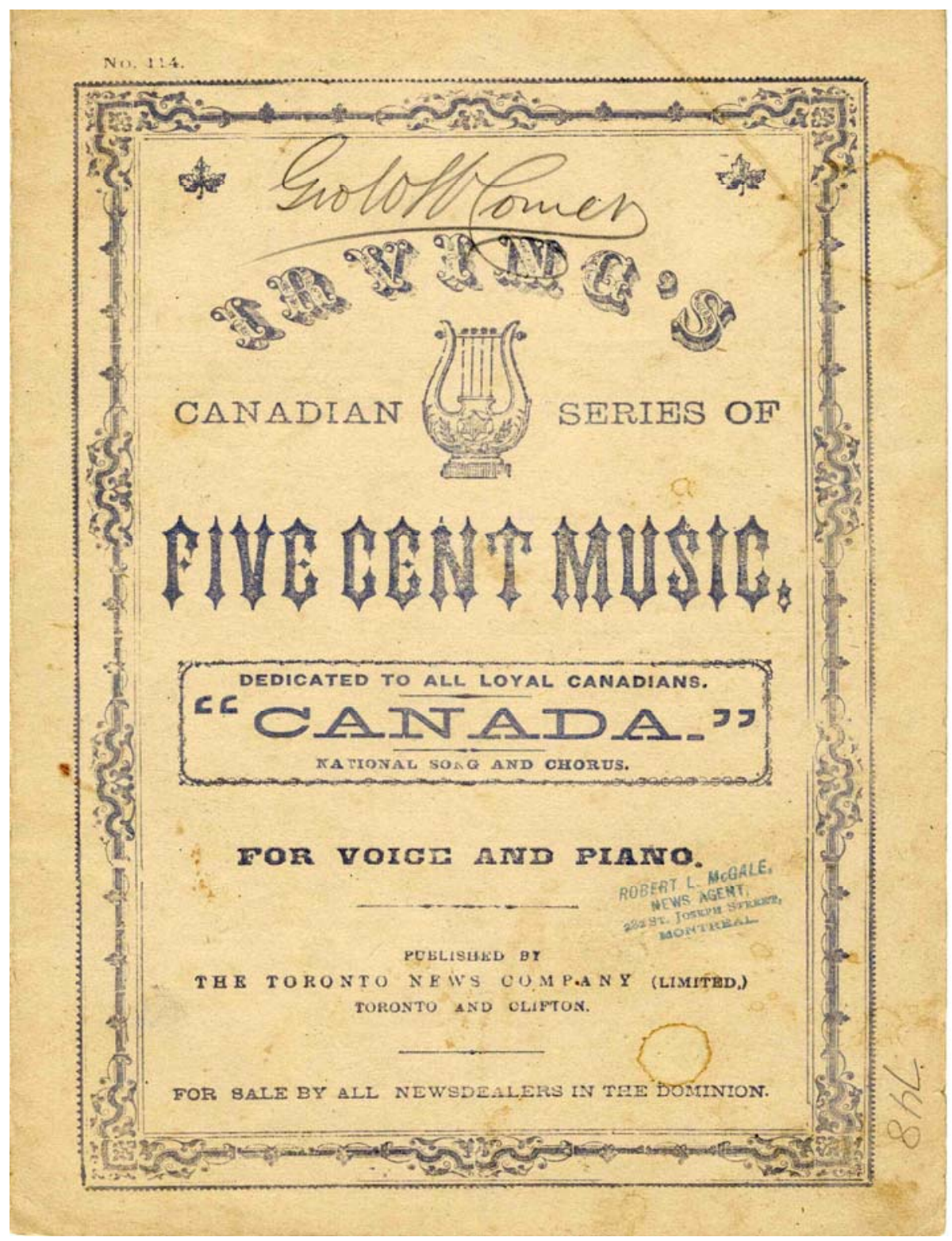

The Sheet music from Canada's past web site includes three piano pieces by Frances J. Hatton, otherwise known as Mrs. Chas. G. Moore. It does not, however, include "Canada," a national song and chorus, which is "dedicated to all loyal Canadians." Apparently, it was first published in Belford's magazine in 1878 (Kallmann 1992a, 637), and was perhaps intended as a possible national anthem in English to match the rising popularity of Lavallée's "Chant national," which, of course, was later to be known as "O Canada." 


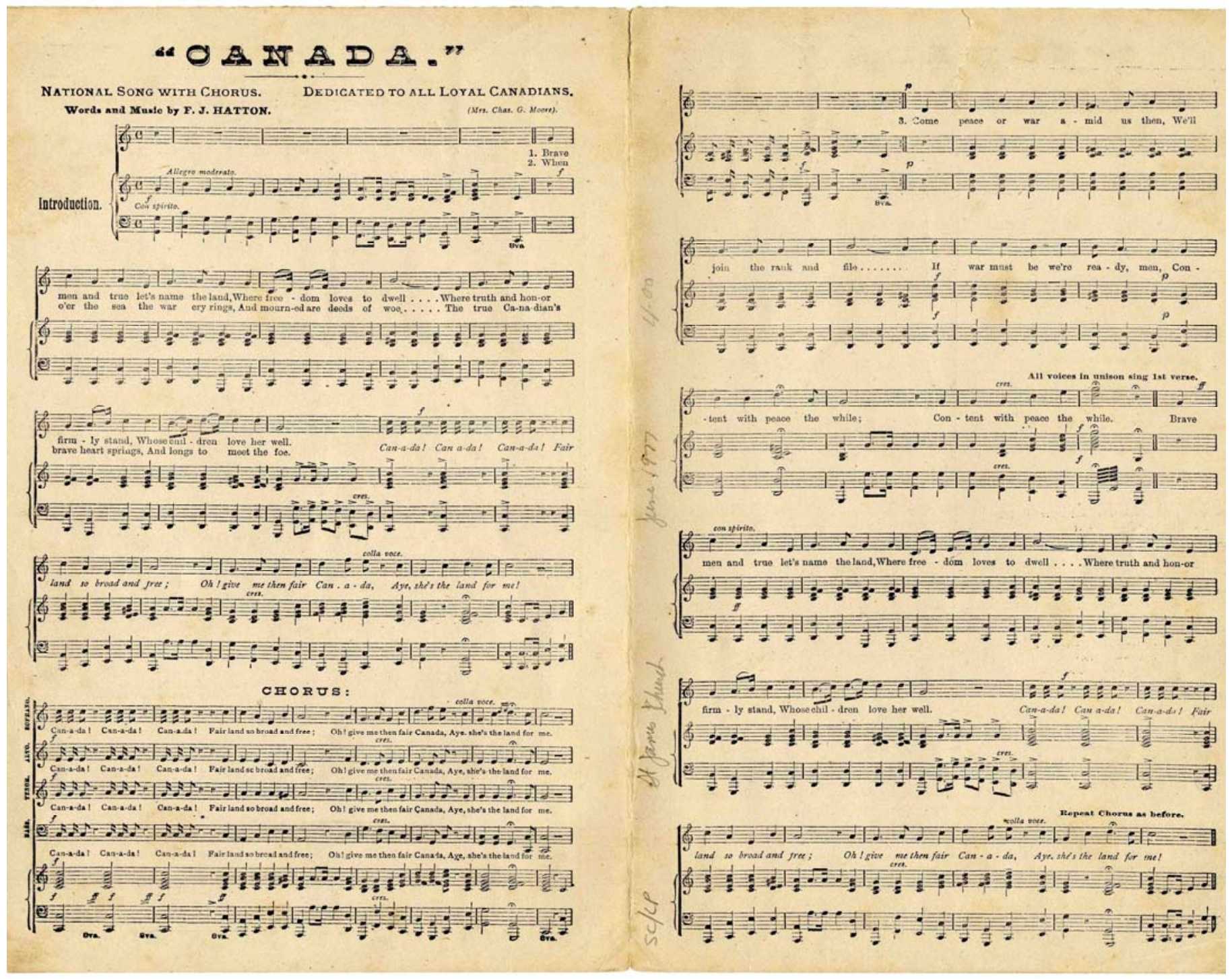

One of the most popular patriotic songs, and among the most renowned of all the songs of Irving's Canadian series of five cent music, is "The Maple Leaf, our Emblem Dear." It predates Hatton's and Lavallée's national songs, as words and music were composed in the year of Confederation by Alexander Muir (1830-1906) (Kallmann 1992b, 802). The first publication of it, probably in 1868 though without copyright notice, and two other editions published in Toronto in 1871 and 1897, are reproduced on the web site Sheet music from Canada's past. The Five Cent Music version must have been issued before 1880. It remained one of the few songs published in the sheet music Series with a distinctive Canadian importance and appeal, and thus is an indicator in itself of the significance and role which Irving's Canadian series of five cent music played in Canada's musical development. 


\section{Appendix 1: Song Titles with Series Numbers}

Adieu, Sweetheart, but not Good-bye 181 After the ball 732

After the Storm is Past 547

Aileen Aroon 299

Allena 504

Alone in the Street 575

Always Show Respect, Joe! 718

Always Take Mothers Advice 621

Amber Tresses tied in Blue 57

Angel Gabriel 240

Angels are Watching Above 460

Angels Called Thee, Little Darling 484

Angels Meet Me at de Cross-roads 104

Angels Whisper soft Good-night 173

Angels will open the Beautiful Gates 448

Annie o' the Banks o' the Dee 138

Annie Rooney's Baby 719

Annie Rooney's Sister 716

Are We Forgotten when Were Gone? 96

Are you there, Moriarity 223

As Good as Gold 121

As I sat upon my dear old Mother's Knee 614

As long as the World goes round 557

As She went Passing by 154

Au Elegant Irish Gentleman 704

Autograph Album 578

Babies on our Block 213

Baby Mine 177

Baby's Gone 149

Baby's Laughing in Her Sleep 655

Baby's Tears 715

Balm of Gilead 421

Banks of Conway 684

Barney Machree 270

Barney McCoy 412

Barney take me Home Again 607

Barney, Come Home 707

Barney, Don't Forget 193

Beautiful Child of the Street 556

Beautiful Dreamer 280

Beautiful girl of Kildare 55

Beautiful Isle of the Sea 109

Beautiful Nell 144

Beware 141

Bidalia McCann 231

Birdie has Come 6

Birdie you must never Tell 158

Birdie, tell Winnie I'm Waiting 113

Birds will Come Again 146

Black-eyed Binie's gone to Rest 432

Blind Mother 693

Blow the Bellows, Blow 590

Boat Song 570

Bonnie Sweet Bessie, the Maid o' Dundee 286

Boodle 565

Bo-Peep 490

Boston Fire 351

Boy's best Friend is his Mother 543

Brannigan's Band 197

Break the News gently to Mother 312

Bright flays of Early Morning 108

Bring Back My Fisher Boy 610

Bring me a Letter from Home 438

Bring the Absent back to me 496

Broken Down 331

Broken Playthings on the Floor 613

Brooklyn Theatre Fire 535

Brown Eyes Close to the Window 404

Bury me Neath the Old Home 515

Butterfly Dude 598

By and by You Will Forget me 434

Bye-bye, Baby bye-bye 520

Call her Back and Kiss Her 153

Call Me Back Again 554

Campbells are Coining 196

Canada 114
Cantilena 48

Carry me back to old Virginny 242

Cast One Little Thought for Me 518

Castles in the Air 120

Cat Came Back 741

Charming Little Ada 485

Charming Little Bo-Peep 571

Chiming of the Bell 573

Climbing the Golden Stair 295

Climbing up de Golden Stairs 560

Cobwebs on the Wall 540

Come again To-morrow Night 10

Come along, my Darling 635

Come Back to Erin 32

Come Down Mrs. Flynn 721

Come o'er the Lake 301

Come sit by my Side, little Darling 4

Come, Birdie Come 9

Coming home From Meeting 541

Convict and the Bird 666

Cottage by the Sea 263

Cows are in the Corn 292

Cradle isn't Empty, Baby smiled 391

Cradle's Empty, Baby's Gone 340

Creep into Bed, My Baby 619

Cricket on the Hearth 634

Daffney, do you Love me 303

Dancing in the Barn 309

Dare to do Right 51

Darling Bessie of the Lea 151

Darling Minnie Lee 209

Day when you'll Forget me 267

Days that are gone Seem the Brightest 454

De Angels am a Coming 417

De day I was Sot Free 318

De Golden Wedding 311

De Huckleberry Pic-nic 313

Dear Little Colleen 184

Dear Little Isle Fat Away 188

Dear Little Pansy Blossom 470

Denny Grady's Hack 652

Dese Bones shall rise again 304

Died in the Streets 282

Dimpled Hands 468

Dip Me in de Golden Sea 414

Do not turn me from your Door 53

Don't be angry, Mother 489

Don't be Crying, Little Girl 402

Don't be Sorrowful, Darling 116

Don't Forget a Friend 459

Don't Forget me, Darling 236

Don't Forget the Firesid

Don't give up the old Friends for the new 588

Don't go out To-night Dear Father 513

Don't leave Grandmother now she's old 79

Don't you cry so, Nora Darling 67

Don't you go, Tommy 164

Don't you miss the Train 358

Dot Leedle Yawcob Strauss 80

Down Amid the Clust'ring Roses 352

Down among de Sugar Cane 61

Down among the Daisies 681

Down the shadowed Lane she goes 93

Draw aside the Curtain, Mother 278

Draw the Line at That 539

Dream of Love is o'er 305

Dreaming and Drifting 201

Dreaming of Home and Mother 72

Dreamy Eyes are Closed or ever 457

Drifting 136

Drifting down to Sea 314

Drifting With the Tide 246

Driven from Home 112

Dublin Bay 84

Dying Nun 383

Eileen Alanna 66
Ellie Rhee 81

Eva 207

Evening News, or "Ragged Matt" 738

Exile's Lament 629

Eyes that Stole my heart away 549

Faded Pansy 562

Fairies Watch our little Darling 680

Fairy Footsteps Gently Falling 273

Far Away 83

Father Says I May 3

Father, bring Home your Money 28

Father's Growing Old 338

Fifty cents 491

Finger Prints upon the Pane 446

Finnigan and his Flute 365

Fisherman and his Child 568

Five O'Clock in the Morning 143

Flower from Mother's Grave 217

For you are Praying at Home 395

Found Dead in the Street 493

Free as the Air 266

Fritz's Lullaby 337

Gallagher's Baby 692

Gates are Wide Open 58

Gathering Shells from the Sea Shore 38

Gathering the Myrtle with Mary 626

Gently down the Stream of Time 30

Give an Honest Irish Lad a Chance 482

Give the Poor all they honestly Earn 426

God Bless my dear old Mother 241

Golden Picture of Home 596

Golden Stair 256

Golden Years are passing by 214

Gone Before 128

Good Evening 155

Good old Jeff; or, the Poor Old Slave 255

Good-bye, Katie Darling 597

Good-Bye, Mavourneen 572

Good-Bye, Mavourneen 480

Good-bye, Old Cabin Home 537

Grandfather's Clock 101

Grandma's Vacant Chair 611

Grandmother's Chair 261

Gray Hairs of my Mother 204

Grogan the Masher 600

Hand that Rocks the World 583

Hannah, Boil dat Cabbage Down 316

Has Father been Here? 298

Haunting Eyes 103

Have I not been Kind to Thee 63

He ain't in it 712

He holds the Fort of Heaven 78

He never Smiled Again 268

He's the Picture of his Daddy 606

Hear Dem Bells 664

Her Bright Smile haunts me Still 133

Her Own Boy Jack 649

High-Water Pants 344

Hildebrant Montrose 62

Home Again 371

Homeless and Alone To-night 310

Homeless To-night 171

Hope 162

How I miss those Little Footsteps 277

How Paddy Stole the Rope 689

How the Gates came Ajar 11

Hush, Little Baby, Don’t you Cry 601

Hush, my Darling, do not Cry 469

I Cannot Sing the Old Songs 211

I Don't Want to Play in Your Yard 743

I Guess you have All been There 445

I had Fifteen Dollars in my Inside Pocket 640

I Have No Home 2

I know you'll be true to me, Robin 105

I know, Love, you'll be True 60

I Like it, I do 647 
I love the Merry Sunshine 137

I Loved You Better than You Knew 748

I Owe $\$ 10$ to O'Grady 660

I want to see my Little Girl again 553

I will be True to Thee 410

I Will Return Again 659

I wish he'd make up his Mind 530

I'll await my Love 56

I'll be all smiles to-night 676

I'll be Watching for you at the Window 182

I'll bet you a Dollar you don't 343

I'll go back to Erin 288

I'll Meet You when the Sun Goes down 464

I'll Remember You in my Prayers 376

I'll Rock me to Sleep in my Grandmother's Chair 592

I'll see that your Grave is Kept Green 321

I'll Take you Home again, Kathleen 450

I'll Wait till the Clouds Roll by 503

I’ll Wait Till the Clouds Roll By 579

I'm a Dude 510

I'm a Hustler 645

I'm Dying for Some One to Love me 437

I'm Glad my Heart's my Ain yet 360

I'm Going Home to Chloe 399

I'm going to Write to Papa 502

I'm One of the Ticklish Kind 447

I'm so shy 648

I'm Still a Friend to You 473

I'm thinking of Mamma in her Grave 505

I'm Waiting, my Darling, for Thee 13

I'se Gwine back to Dixie 186

I'se Gwine to Alabama 497

I've Called you back Again, Kathleen 587

I've no mother 334

I've only been Down to the Club 202

If the Waters could Speak 679

In her Little Bed We Laid Her 122

In His Mind 474

In the Evening by the Moonlight 380

In the Gloaming 271

In the Morning by the Bright Light 239

In the Twilight I am Dreaming 551

Irene, Good Night 739

Irish Christening at Tipperary 603

Irishman's Toast 624

Is it wrong to Kiss? 550

Is that Mr. Reilly? 476

It's English You Know 616

Jennie, the Pride of Kildare 234

Jenny who Lives in the Dell 134

Jenny, my Loved one 483

Jerusalem the Golden 131

Jim Fisk 200

Jim, the Carter Lad 327

John Riley's always Dry 346

Juanita 208

Just a Little Sunshine 669

Just to Pay our Respects to Maguiness 638

Kathleen 698

Kathleen Aroon 21

Kathleen Mavourneen 85

Kathleen of Kilkenny 253

Kathleen's Answer 142

Katie Molloy 722

Keep dem Golden Gates Wide Open 384

Keep Hammerin' 608

Keep in the Middle of the Road 36

Keep pretty flowers on my Grave 248

Keep the horse-shoe over the Door 400

Killarney 210

Kiss and Forget, Love 176

Kiss me and call me your Darling 274

Kiss me and I'll go to Sleep 152

Kissing Sunbeams 452

Last Sweet Words of Mother 533

Lay aside the little Shoes and Stockings 319

Laziest Man in all the Town 330

Leave Me not in Anger 415

Led Astray 12
Lessons Learned at a Mother's Knee 674

Let me be 126

Let the Dead and the Beautiful Rest 308

Let these Kisses say Farewell 501

Let your Tears Kiss the Flowers 300

Letter came at Last 643

Letter that Never Came 639

Letter to the Old Folks 574

Light in Nellie s Eyes 623

Lighthouse by the Sea 622

Linger near Me, Little Darling 175

Little Blonde in Blue 89

Little Bow of Blue 189

Little Boy Blue 668

Little bright Eyes at the Window 90

Little Brother Joe 429

Little Brown Jug 41

Little Daisy 21

Little Emily 159

Little Footsteps 14

Little German Home across the Sea 350

Little Jessie 279

Little Mag and I 413

Little Maggie Ann 471

Little Maggie, the Pride of Kilvane 406

Little May 24

Little Mollie Brown 23

Little Old Cabin in the Lane 34

Little One Whisper you love me 508

Little Ones at Home 46

Little Rosebud 287

Little Sister's gone to Sleep 205

Little Spring beside my Home 218

Little Stars are brightly Shining 47

Little Sunshine 8

Little Sweetheart, come and Kiss Me 17

Little Widow Dunn 232

Little Wife Nellie, the light of my Home 377

Lost Letter 580

Love and Be True 569

Love at Home 521

Love Letters 720

Love Lives for Ever 714

Love Will Roll the Clouds Away 465

Love's Chidings 315

Loved Ones Far Away 179

Loved Ones Passed Away 456

Lovers once, but Strangers now! 711

Madeline 702

Madoline 724

Maggie Darrow's Welcome 617

Maggie Murphy's Home 725

Maggie's Welcome 139

Maid of a Mountain Land 685

Make believe I'm l)reaming 165

Man Behind the Plough 48

Man in the Moon was looking 172

Man o’ Airlie 129

Man That Struck O’Hara 651

Maple Leaf, our Emblem Dear 269

Marching Through Georgia 390

Marchioness 333

Mary Aileen 98

Mary Ann McLaughlin 427

Mary Kelly's Beau 627

Mary Smiled the Clouds Away 462

Mary's Gone with a Coon 42

Massa's in the Cold Ground 667

McDonnell's Old Tin Roof 424

McSorley's Twins 291

Meanest Folks on our Block 328

Meet me at Twilight 293

Merriest Girl that's Out 14

Midnight Fire Alarm 514

Midnight Fire Alarm 618

Milwaukee Fire 536

Mirror's the Cause of it all 387

Miss Brady's Piano For-tay 451

Miss Fogarty's Christmas Cake 534
Miss Gruber’s Boarding House 329

Mister Dooley's Geese 589

Moet and Chandon 119

Mollie Darling 1

Mollie Mavourneen 366

Mollie's Answer 5

Molly is waiting for me 706

Moonlight at Killarney 443

Mora Marie 416

Morning Lark 661

Mother Comes to Me in Dreams 407

Mother Dear Draw Near to Me 577

Mother is the Best Friend 529

Mother Kissed me in my Dream 362

Mother Told Me So 665

Mother, is the Old Home Lonely 25

Mother, take me Home again 157

Mother's Calling Baby Home 397

Mother's Darling Boy 546

Mother's Last Letter to me 555

Mother's Last Letter to me 559

Mother's Last Request 593

Mrs. Brady's Daughter 422

Mrs. Murphy's Boy Dennis 646

Mulligan Guards 22

Mulligan's Funeral 382

Must we Leave Thee? 506

Must We then Meet as Strangers 56

My Angel Mother 357

My Bonnie, Blue-Eyed Lad 558

My dad's the engineer 749

My Home on the Old Ohio 249

My Little Side Door 542

My Love to All at Home 59

My Maggie 694

My Mother's Dear Old Face 347

My Mother's dear old Face 682

My Nellie's Blue Eyes 517

My poor heart is sad with its Dreaming 69

My pretty Red Rose 230

My Sailor Lad's Return 653

Nancy Lee 167

Nearer the Beautiful Gates 29

Neath the Maple by the Mill 420

Nestle me close to your heart 332

Never take No for an Answer 657

Never take the Horse-shoe from the Door 381

Never to Meet Again 670

Ninety and Nine 42

No Work 235

Nobody home but Me 545

Nobody's Darling 132

Nobody's Darling but Mine 64

Nora O'Neal 260

Norah Mavourneen 354

Norah, the Pride of Kildare 264

Noreen Maureen 220

Now I Lay Me down to Sleep 221

Now That's What I think, Don't You 709

O! Saviour of the World 206

O, Mother, come back to your Boy 265

O, Restless Sea 697

Oh! Mama, Buy Me That 717

Oh, ain't He Sweet on Me 123

Oh, de Darkie's home am Lonely 290

Oh, dem Golden Slippers 243

Oh, I'll meet you dar 396

Oh, My! How We Pose 594

Oh, Nannie, Wilt thou gang wi'me 297

Oh, Tom, tell them to Stop 342

Old Black Joe 68

Old Cabin Home 374

Old Chimney Corner 275

Old Fashioned Roses are Sweetest 695

Old Folks at Home 75

Old Home ain't what It used to be 190

Old Home down on the Farm 703

Old Log Cabin in the Dell 25

Old Man ain't What he used to be 302 
Old Man’s Drunk Again 118

Old Musician and his Harp 35

Old Rustic Bridge by the Mill 425

Old Wooden Rocker 228

Old-fashioned Photograph of Mother 408

Ole Plantation Home 418

On the Banks of the Beautiful River 306

One Horse Open Sleigh 690

One more River to Cross 296

One Smile for Me, Sweetheart 615

Only 37

Only a Baby's Tiny Shoe 644

Only a Crave on time Door 472

Only a Letter 591

Only a Pansy Blossom 467

Only a Picture of Her Boy 69

Only a Rose from Mother's Grave 363

Only a Violet 523

Only a Workingman's Child 463

Only an ivy Leaf 368

Only Speak Kindly to Me 102

Only Tired 696

Only to see her Face again 356

Order of Full Moons 324

Our Cot in Tennessee 436

Our Good Old Friends 31

Out in the Snow 423

Out of Work 359

Over the Garden Wall 341

Over the Hill to the Poorhouse 43

Over the Mountain 630

Papa's Baby Boy 527

Papa's Footsteps 687

Papa's Footsteps 701

Pardon Came Too Late 737

Pass under the Rod 45

Pass us not By 430

Pat and His Little Brown Mare 586

Patter of the Shingle 449

Paving the Way 130

Peek-a-Boo! 440

Peep Out of the Window 650

Peggy O'Moore 632

Pen and the Press 528

Phantom Footsteps 405

Picture turned toward the wall 726

Please Give me a Penny 478

Please God, make room for a little Boy 18

Please Sell no more Drink to my Father 595

Poor Little Joe 486

Poor Little Johnny 585

Poor Old Dad 612

Poor old Tramp 247

Prayer on the Pier 479

Pretty as a Picture 65

Pretty Little Cottage in the Meadow 455

Pretty Little Dark-Blue Eyes 609

Pretty Little South Carolina Rose 367

Pretty Pond Lilies 544

Pull Down the Blind 36

Put me in my Little Bed 117

Put on my Long White Robe 323

Queen Victoria's Jubilee 631

Rain upon the Roof 244

Razors in the Air 375

Razzle Dazzle 683

Regular Army, O 166

Remember you have Children 229

Remember, Boy, you're Irish 628

Riding in a Pullman Car 140

Ring my Mother Wore 258

Ring the Bell, Watchman 259

Rise it, Riley 322

Robin, tell Kitty I'm Coming 233

Rock Dat Ship 663

Rock-a-bye Baby 625

Rollin' to de Sea 567

Rolling Stone gathers no Moss 566

Roman Fall 161
Rose-Bush by the Gate 481

Roses Underneath the Snow 252

Sadie Ray 99

Safely Rocked in Mother's Arms 671

Sailor's Return 581

Save the Boy 127

Scanlan's Rose Song 511

Scanlan's Swing Song 678

Scotch Lassie Jean 339

Secrets 135

See that my Grave’s kept Green 94

Send me a Rose from my Mother's Grave 582

Sequel to Grandfather's Clock 225

Shadows on the Floor 227

Shells upon the Shore 373

Shells We Gathered Years Ago 224

Shining Curls of Gold 372

Ship that Never Returned 605

Shivering and Shaking out in the Cold 317

Silver Stars are Softly Gleaming 106

Silver Threads among the Gold 16

Since Benny went Over the Sea 519

Sing to me, Robin. 294

Six Feet of Earth 662

Skidmore Guard 33

Skids are out to-day 284

Slavery Days 195

Sleep, my Little Blue-eyed Treasure 92

Sleeping 'Neath the Fair Spring Flowers 198

Slightly on the Mash 512

Softly Sing the Old Songs 178

Some Day I'll Wander Back Again 431

Somebody's Coming 219

Something Sweet to think of 336

Song of the Steeple 735

Song that reached my heart: home, sweet home 733

Sons of Ham 386

Spanish Cavalier 604

Speak to me 97

Spider and the Fly 492

Standard of England 636

Standing on the Platform Waiting for the Train 156

Star of the Evening 160

Starlight on the Sea 466

Starry Night for a Ramble 40

Stealing a Kiss at the Garden Gate 150

Still I love Thee 147

Stitch in Time Saves Nine 675

Strangers Yet 212

Strolling on the Sands 7

Sweet as a Peach 441

Sweet Bunch of Daisies 750

Sweet Bye and Bye 168

Sweet Eyes of Irish Blue 705

Sweet Face at the Window 276

Sweet Genevieve 107

Sweet Heather-Bell 642

Sweet Little May 509

Sweet Marie 740

Sweet Mary Ann 215

Sweet sunny smile of my Darling 88

Sweet Violets 494

Sweetest Love, I'll not Forget 70

Take Me Back Home 475

Take Me back to Home and Mother 453

Take Me Home 245

Take me to the Ball to-night 125

Take this Letter to my Mother 185

Talk about your Moses 394

Tar's Farewell 238

Tenting on the Old Camp Ground 389

That Husband of Mine 95

That Melody Divine 658

That Song of Thine 110

That won't Keep a Wife and Baby 435

That's the reason why! 700

There are Kisses waiting for me 353

There are Strangers on the Old Farm 730

There goes Major Casey 699
There Goes McManus 713

There is an Eden Bright and Fair 686

There's a Dear Spot in Ireland 499

There's a Letter in the Candle 54

Thinking and Dreaming of Mother 226

Third Degree Full Moon 349

Thou hast wounded the Spirit that loved 370

Three Angel Visitants 49

Three Calls 50

Three Leaves of Shamrock 708

Tidings of Comfort and Joy 564

Till the Clouds go By 169

Tim Flaherty 27

Time may steal the Roses, Darling 307

Tiny hands 398

Tis but a Little Faded Flower 163

Tis darkest just before the Day 285

Tis for Money 633

To Love and be Loved 552

To-day and To-morrow 82

Tommy make Room for your Uncle 74

Touch me gently, Father Time 87

Touch the Sleeping Strings 409

Trabling Back to Georgia 76

Tread Softly, Angels are Calling 531

True as the Stars that are Shining 532

Twas the Master that Knocked 73

Twenty-seven Cents 192

Twickenham Ferry 326

Twilight Coterie 325

Twinkle, Twinkle, Little Stars 281

Two Little Girls in Blue 736

Two Orphans 401

Uncle Tom's Gwine to Stay 411

Uncle Tom's Lament 237

Under the Chestnut Boughs 584

Under the Daisies 111

Under the Moon-lit sky 516

Under the Roof-tree 498

Vacant Chair 526

Vine-covered Cottage 194

Violet from Mother's Grave 348

Volunteer Organist 742

Wait till the Clouds Roll by 419

Wait till the Moonlight falls 91

Wait Till The Tide Comes In 656

Waiting 'Mid the Pansies 524

Waiting a Letter from over the Sea 548

Wake Nicodemus 433

Watching the children play 734

Water Mill 199

We Never Speak as we pass by 461

We Ought to be Thankful for that 710

We Parted by the River Side 257

We shall Meet all the Little Ones there 183

We'd better Bide a Wee 44

We've Both been There before Many a Time 673

What is home without a Mother? 369

What is it? 335

What kind of Shoes you gwine to wear 392

What sin a Kiss 599

What were all the World without Thee 77

Wheel the Baby out 345

When Autumn Leaves turn Red and Gold 458

When I Mean to Marry 507

When Jamie comes over the Sea 272

When Leaflets from toe Roses fall 180

When Little Mamie Died 20

When My Rover Comes Again 576

When Nellie was Raking the Hay 620

When Silver Locks replace the Gold 19

When the Flowers fall Asleep 364

When the Leaves begin to Turn 378

When the Little Birds are singing in the Garden 654

When the Mists have Rolled Away 86

When the Moon Shines Bright 538

When the Moon-Beams Fall 477

When the Robins nest Again 522

When the Roses come Again 442 
When We meet in the Sweet Bye and Bye 289

When you and I Were Young, Maggie 254

Where are the Angels, Mother? 385

Where is Heaven? 393

Where is my Boy To-night? 488

Where pretty Violets Grow 320

Where the Moonbeams love to smile 191

Where the Woodbine Twineth 115

Whip-poor-Will 222

Whip-poor-Will's Song 15

Whisper softly, Mother's Dying 52

Whispering Hope 495

Whist! The Bogie Man 723

Whistling Coon 688

White Wings 602

Who's dat Callin' so Sweet? 64

Whoa Emina 203
Why did the Angels take Mamma away 439

Why does Mother stay so long? 187

Why Paddy's always Poor 637

Why was I Looking out? 148

Widow in the Cottage by the Sea 388

Widow Nolan's Goat 444

Will Mother know me in the Sky 170

Will the Dear Old Times come back 403

Will You Remember Me 250

Will you Love me when I'm Old 174

With all her faults I love her 672

Would I Were With Thee 39

Write to me Often 71

Yakie and Leedle Louvise 283

You and I! 100

You and I, Love 677

You are always Young to Me 26
You Can’t Always Tell 355

You Can't Play in Our Yard any More 744

You know how it is Yourself 124

You'll miss your Mother when she's gone 563

You've Been a Friend to Me 262

Your Lassie Will be True 379

Your Pocket Book’s Your Friend 500 


\section{Appendix 2: Known Composers}

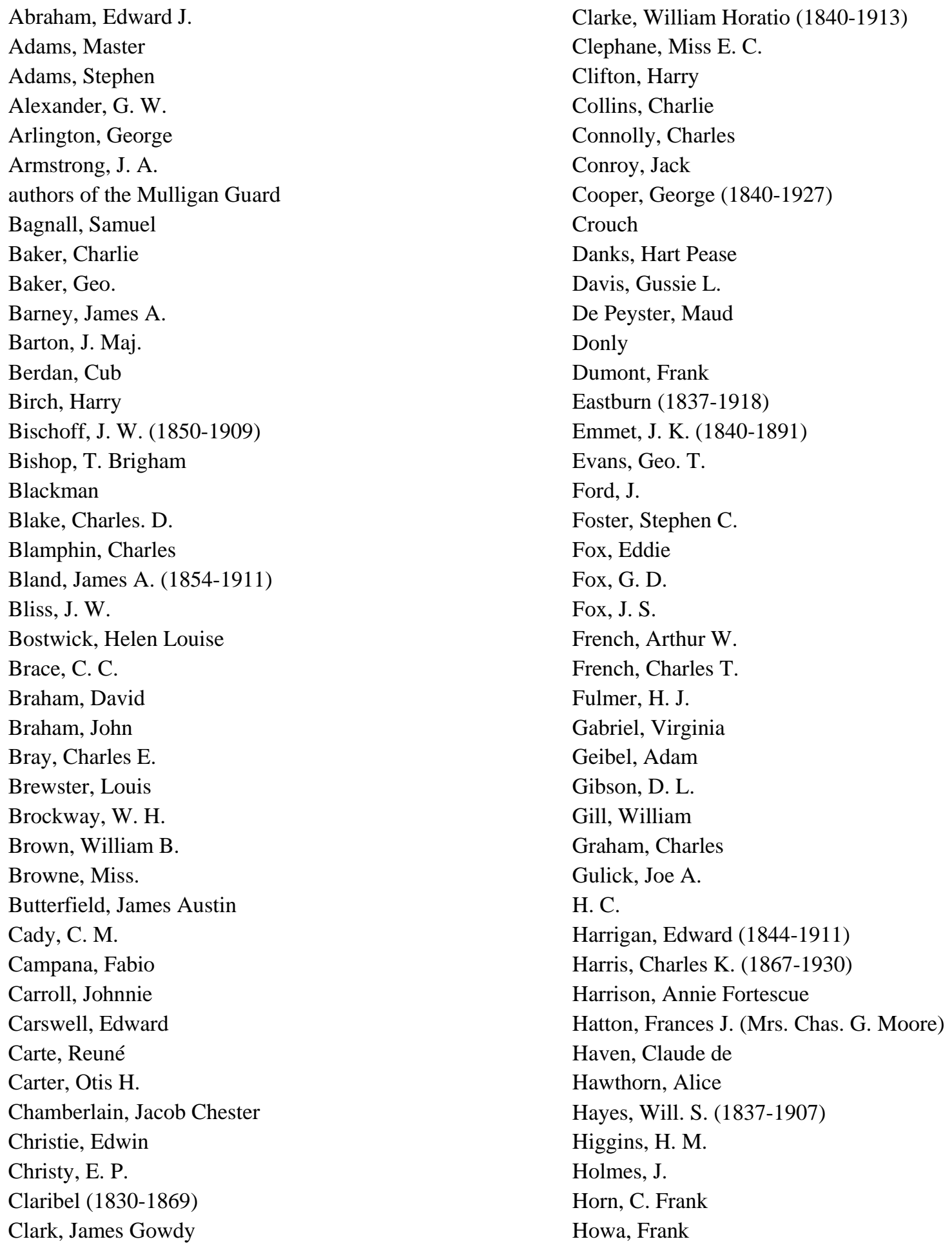


Howard, Frank

Hoyes

Hughes, C. H.

Huntley, William A.

Johnston, Archibald

Jones, Thomas

Jordan, Julian

Jordan, Leopold

Keily, Harry P.

Kelley, J. W.

Kelley, T. B.

Kennedy, Harry

Konollman, Charlie (1843- )

Lang, Alfred

Lavallée, Calixa

LeCroix, Jean

Lee, Alfred

Leslie, Herbert

Levoy, Leon

Lockwood, C. T.

Lonsdale, T. S.

Lucas, Sam (1840-1916)

MacEvoy, Fred.

Macy, James C.

Marzials, Theophilus Julius Henry

Maxwell, Harry

McNaughton, J. H.

Miers, Chas. J.

Millard, Harrison (1830-1895)

Milton, W. S.

Minasi, Carlo

Mitchell, Sam'l N.

Moulton, Charles

Muir, Alexander

Mullaly, W. S.

Nannie

North, J. M.

Norton, Hon. Mrs.

O'Neil, Jim

Ordway, J. P.

Owen, Anita

Packard, William A.

Peabody, J. H.
Persley, George W.

Pratt, Charles E.

Pyke, C. M.

Read, John

Rexford, Ebon E.

Rimbaulet, Edward Francis

Rogers, Wm. T.

Rosabel

Rosenfeld, Monroe H.

Rutledge, John T.

Sankey, Ira D.

Scanlan, Wm. J.

Schleiffarth, Geo.

Scott, Sue Ingersoll

Sherman, Wm. F.

Sinclair, W. F.

Skelly, Joseph P. (1853-1895)

Smith, Dexter

Smith, T.

Stanley, Harry C.

Stewart, James E.

Straight, Ned

Sturm, Max

Tannenbaum, J.

Taylor, Judson

Thomas, John Rogers

Thompson, Will L.

Tompkins, Clara

Tucker, Henry

Vicars, George M.

Von Thilo, W.

Wambold, D. S.

Webster, J. P.

Westendorf, Thomas P.

Wheeler, J.W.

White, Charles Albert

Williams, Ben

Williams, Gus

Winner, Sep.

Winter, Banks

Woodbury, I. B.

Work, Henry Clay

Wrighton, W. P. 


\section{References}

Amicus: Canadian national catalogue. http://www.collectionscanada.gc.ca/amicus/index-e.html. (accessed 8 April 2009).

Hall, Frederick A., ed. 1985. Songs I to English texts = Chansons I sur des textes anglais. Ottawa: Canadian Musical Heritage Society = Société pour le patrimoine musical canadien.

Hulse, Elizabeth. 1982. A dictionary of Toronto printers, publishers, booksellers and the allied trades: 1798-1900. Toronto: Anson-Cartwright Editions.

Kallmann, Helmut. 1988. Music publishing. In The Canadian encyclopedia., ed. James H. Marsh. Vol. 3, 1419. Edmonton: Hurtig Publishers. http://www.thecanadianencyclopedia.com/index.cfm?PgNm=TCE\&Params=A1SEC824780 (accessed 12 February 2009).

.1992a. Irving's Canadian series of five cent music. In Encyclopedia of music in Canada, ed. Helmut Kallmann and Gilles Potvin, 637. Toronto: University of Toronto Press.

— 1992b. The maple leaf for ever. In Encyclopedia of music in Canada, ed. Helmut Kallmann and Gilles Potvin, 802. Toronto: University of Toronto Press.

Kallmann, Helmut, and Gilles Potvin, ed. 1992. Encyclopedia of music in Canada. Toronto: University of Toronto Press. http://www.thecanadianencyclopedia.com/index.cfm?PgNm=EMCSubjects\&Params=U2.

Krummel, D.W., and Stanley Sadie, ed. 1990. Music printing and publishing. London; New York: Macmillan; W.W. Norton.

Library and Archives Canada. Sheet music from Canada's past. http://www.collectionscanada.gc.ca/sheetmusic/.

List of Irving's five cent music: containing all the new and popular songs of the day. 1890. Saint John, N.B.: Landry \& Co.

Miller, Mark. 1992. When you and I were young, Maggie. In Encyclopedia of music in Canada, ed. Helmut Kallmann and Gilles Potvin, 1399. Toronto: University of Toronto Press.

Parker, George L. 1985. The beginnings of the book trade in Canada. Toronto: University of Toronto Press. 
Potvin, Gilles. 1992. Lavallée. In Encyclopedia of music in Canada, ed. Helmut Kallmann and Gilles Potvin, 726-729. Toronto: University of Toronto Press.

Southworth, Emma Dorothy Eliza Nevitte. The hidden hand. Toronto and Niagara Falls: Toronto News, [1874-1876]. CIHM no. 92361. Ottawa: Canadian Institute for Historical Microreproductions, 1993.

WorldCat catalogue. http://www.worldcat.org/. (accessed 10 March 2009). 